\title{
Opiorphin Secretion Pattern in Healthy Volunteers: Gender Difference and Organ Specificity
}

Dufour $E^{1}$, Villard-Saussine $\mathbf{S}^{1,2}$, Mellon $\mathbf{V}^{3}$, Leandri $\mathbf{R}^{4}$, Jouannet $\mathbf{P}^{4}$, Ungeheuer $\mathbf{M N}^{3}$ and Rougeot $\mathbf{C}^{\text {** }}$

${ }^{1}$ Pasteur Institute, Laboratory of Pharmacology of Pain, Department of Structural Biology and Chemistry, Paris cedex, France ${ }^{2}$ Bio-Rad, 9 Avenue du Canada 91959 Courtaboeuf Cedex, France

${ }^{3}$ Pasteur Institute, Platform Clinical Investigation and Access to Biological Resources (platform ICAReB), Paris cedex, France ${ }^{4}$ Cochin Hospital, Laboratory of Reproductive Biology - CECOS, Paris cedex, France

\begin{abstract}
Background: Opiorphin is an endogenous human peptide regulator of enkephalin bioavailability. It inhibits enkephalin-inactivating ectopeptidases to produce analgesia and antidepressant-like effects in standard rodent models via activation of $\mu$ and/or $\delta$ opioid pathways. Our aim was to establish the quantitative profile of secretion and distribution of this regulator in young adult volunteers.

Methods: We developed a specific ELISA-based method, in tandem with RP-HPLC chromatography, to determine opiorphin levels in blood, urine, semen and milk of healthy male and female volunteers. We also investigated the presence of the mature opiorphin in tears and saliva because it was previously reported that PROL1 gene, encoding opiorphin precursor, is primarily expressed in human lachrymal and salivary glands.

Results: Opiorphin circulates as an endocrine messenger in the human bloodstream at $0.3-1.1 \mathrm{ng} / \mathrm{ml}$ median ranges. Its physiological concentration under basal conditions is higher in males than in females while it is significantly lower in sixth month pregnant compared to non-pregnant volunteers. It is eliminated in the urine with a significant higher rate in men compared to women. Opiorphin is distributed, at rates 10 times higher than in plasma, in the semen of normozoospermic donors and in the milk of lactating women as both free molecular and cation mineral-binding forms. Opiorphin is secreted in tears and saliva at the highest physiological concentrations, demonstrating that salivary and lachrymal glands are the tissues of major expression and secretion of PROL1 gene mature products.
\end{abstract}

Discussion: Our data, associated with database searches from human transcriptome and our previous functional findings, provide evidence that opiorphin exerts organ-specific and gender-specific functions in human physiological systems through neuroendocrine, paracrine/autocrine and/or exocrine mechanisms.

Keywords: Opiorphin; Inhibitor of enkephalin; Inactivating peptidases; ELISA based assay; Human biofluids; PROL1 gene

\section{Introduction}

Opiorphin, a QRFSR pentapeptide, is an endogenous human peptide regulator that was discovered using a functional biochemical approach [1,2]. It is a physiological dual inhibitor of Zn-ectopeptidases, neutral endopeptidase (NEP EC3.4.21.11) and aminopeptidase N (AP-N EC3.4.11.2), which are implicated in the rapid inactivation of endogenous circulating opioid agonists, namely the enkephalins. Opiorphin protects enkephalins from inactivation by ectoenkephalinases and thus improves the specific binding and affinity of enkephalin-related peptides to membrane opioid receptors [3]. Enkephalins are opioid neuropeptides, which play key roles in the control of nociceptive transmission and in the modulation of the activity of cerebral structures governing motivation and the adaptive balance of emotional states [4,5]. By increasing the half-life of circulating enkephalins, opiorphin, at systemically or centrally active doses $(1-2 \mathrm{mg} / \mathrm{kg}$, iv or $5-10 \mu \mathrm{g} / \mathrm{kg}$ icv), produces analgesia in various rodent models of pain and also antidepressant-like effects in standard rat or mouse models of depression, via endogenous enkephalin-related activation of $\mu$ and/or $\delta$ opioid pathways [1,6-9].

Rat sialorphin (QHNPR peptide) was the first identified natural enkephalin catabolizing inhibitor that induces potent antinociception in mammals $[10,11]$. It is an endogenous androgen-regulated peptide and also modulates, at doses equivalent to physiological circulating levels, male sexual behavior [12-14]. We also demonstrated that sialorphin is an exocrine and endocrine peptide messenger whose major expression in rat salivary and prostate glands is activated by androgen regulation
[15] and whose local and systemic secretion is stimulated under adrenergic-mediated response to environmental stress in male rats $[16,17]$. The physiological range of circulating sialorphin in the plasma of conscious adult male rats is $1.9 \pm 0.2 \mathrm{ng} / \mathrm{ml}$ under resting conditions and $7-12 \mathrm{ng} / \mathrm{ml}$ under adrenergic or acute stress stimulated conditions [16]. Under adrenergic stimulated conditions of anesthetized adult male rats the maximal values in saliva may attain $1 \mu \mathrm{g}$ peptide $/ \mathrm{ml}$ saliva over the $30 \mathrm{~min}$ period of saliva collection $[18,19]$. In addition, we also identified the presence of sialorphin in urine that is excreted through renal glomerular filtration [16]. In female rats, sialorphin is detected in the mammary glands and the placenta and also in breast milk $[11,16]$ (and unpublished observations by Rougeot C).

The exciting discovery of human opiorphin followed from the characterization of rat sialorphin but opiorphin has revealed its own specificity notably in terms of molecular structure as it shares only $40 \%$ sequence similarity with sialorphin peptide. Human opiorphin is the mature peptide product of the PRL1 precursor polypeptide of

*Corresponding author: Catherine Rougeot, Pasteur Institute, Laboratory of Pharmacology of Pain, Department of Structural Biology and Chemistry, France, Tel: 33 (0)1 406134 45; Fax: 33 (0)1 456883 99; E-mail: catherine.rougeot@pasteur.fr

Received June 07, 2013; Accepted June 22, 2013; Published June 25, 2013

Citation: Dufour E, Villard-Saussine S, Mellon V, Leandri R, Jouannet P, et al. (2013) Opiorphin Secretion Pattern in Healthy Volunteers: Gender Difference and Organ Specificity. Biochem Anal Biochem 2: 136. doi:10.4172/2161-1009.1000136

Copyright: $\odot 2013$ Dufour E, et al. This is an open-access article distributed under the terms of the Creative Commons Attribution License, which permits unrestricted use, distribution, and reproduction in any medium, provided the original author and source are credited. 
248 amino acids. The PROL1 gene encodes the secreted preproprotein that contains, in the N-terminal region, the peptide QRFSR. It is intracellularly processed during granule maturation by selective cleavage at consensus sites, i.e., the recognition sites for secretion signal peptidase and for paired basic amino acid convertases (http://www.genecards. org/cgi-bin/carddisp.pl?gene=PROL1). The gene was identified by Dickinson et al in 1996, but was only detected at that time in human lachrymal and salivary glands [20].

The discovery of opiorphin is the first demonstration of the existence of a physiological regulator of enkephalin bioavailability in humans. When the extent of the functions mediated by the endogenous enkephalinergic pathways are considered, the characterization of this upstream modulator of opioid pathways in humans is of major interest from both physiological and physiopathological points of views. Indeed, endogenous human opiorphin appears to intervene in the process of adaptation mediated by enkephalins, which are associated with nociception and emotion-related behaviors. As a consequence, opiorphin could be a biological marker with a potential diagnostic role in various pathological situations, such as hyperalgesic syndromes, depressive states and socio-relational behavioral imbalances.

Here, our objective was to determine the human biological fluids in which opiorphin circulates and to establish its quantitative profile of secretion and distribution in male and female healthy volunteers, in order to then establish an investigative program in patients suffering different pathologies of interest. Based on our previous knowledge of sialorphin expression, samples were collected from the blood, saliva, tears and urine of adult healthy volunteers (male and female, mean age $26 \pm 6 \mathrm{yr})$ and from the milk of lactating healthy women (2-3 wk after delivery) as well as from the semen of healthy donors and of men with congenital bilateral absence of vas deferens (CBAVD).

\section{Subjects and Methods}

\section{Study subjects}

We studied 3 groups of healthy young adult volunteers of $26 \pm 6$ yr mean age. Group 1: opiorphin was measured in the blood, in the salivary and lachrymal secretions and in urines, among male and female healthy volunteers. Group 2: opiorphin production was studied among pregnant women, during the first sixth month of pregnancy, in the blood and saliva and also in their breastfeeding milk during the second to third weeks after delivery. Group 3: analyses were conducted on the sperm of normozoospermic donors $(2.9 \pm 0.4 \mathrm{ml}$ of ejaculate, mean \pm SEM for 11 subjects) after $4 \pm 2$ days of sexual abstinence and also of the blood, urines and salivary secretions. Opiorphin was also measured in the seminal fluid of patients $(1.0 \pm 0.2 \mathrm{ml}$ of ejaculate, mean \pm SEM for 5 subjects) with congenital bilateral absence of the vas deferens (CBAVD), an abnormal anatomy of the male genital tract inducing azoospermia and the ejaculation of semen devoid of the testis, epididymis and seminal vesicles secretions.

Preliminary examination of all subjects was carried out to check for concomitant or severe disorders, clinically significant disease or recent intervention in the oral cavity and for negativity for HIV, HCV or HBV serology. The subjects received no medication (antiinflammatory, analgesic, antidepressant and/or anti-hypertensive) for at least 7 days prior to sampling. They were self-described as nondependent on addictive drugs (alcohol, tobacco). Regarding group 2 , women exhibiting significant pathology during pregnancy, including gestational diabetes and hypertension, were excluded.
Written informed consent was obtained from each subject following a detailed explanation of the purpose of the study, the procedures and the possible risks. This biomedical research study was performed at Institut Pasteur and the associated investigational sites and the study protocol was approved by the French Ethical Committee (so-called Comité de Protection des Personnes) of Cochin Hospital (Paris, France): accession $n^{\circ}$. Am3485-2-2308 on 25th April 2007. The blood, saliva and urine samples of healthy volunteers were provided by the clinical research investigator and associate of the ICAReB platform of Institut Pasteur (Paris, France). The milk samples were obtained from healthy pregnant women from the Unit of Obstetrics of NeckerEnfants Malades hospital and the semen samples from healthy donors and infertile patients from the Unit of Biology of the Reproduction of Cochin hospital (Paris, France).

\section{Study protocol}

Sample collection: Ex vivo, pharmacokinetic and metabolic data reveal that opiorphin, similarly to all peptide mediators of the neuroendocrine system, presents a short metabolic half-life, i.e., about 5 min in human plasma (unpublished observations by Rougeot C). The mixture of peptidase inhibitors previously used for sialorphin detection [16] protected opiorphin from degradation by circulating human peptidases. Thus the biological samples were taken and collected (i.e., $2-5 \mathrm{ml}$ of saliva, $30 \mathrm{ml}$ of whole blood, $20 \mathrm{ml}$ of urine per subject) into previously cooled polypropylene tubes $(4,15$ or 50 ml, Nunc-VWR, France) containing a mixture of peptidase inhibitors: Péfabloc $0.4 \mathrm{mM}$, Aprotinin $1000 \mathrm{KIU} / \mathrm{ml}$, EDTA $1 \mathrm{mM}$, bestatine 150 $\mu \mathrm{M}$, leupeptin $1 \mu \mathrm{M}$ and pepstatin $1 \mu \mathrm{M}$ (Sigma-Aldrich, France). For the semen samples the peptidase inhibitors were limited to $1000 \mathrm{KIU} /$ $\mathrm{ml}$ Aprotinin and $0.4 \mathrm{mM}$ Pefabloc, according to previous validation tests and allowing the examination of spermatozoa concentration and motility in parallel with standard markers. Saliva was collected under two conditions, basal and stimulated: a drop of diluted lemon was applied to the mouth floor to stimulate saliva production. Tear samples were collected after local administration of one drop of saline containing diluted lemon, applied to the inner corner of the eye, to induce the production of tears. Blood samples were centrifuged for 15 min at $300 \times \mathrm{g}$ and $4^{\circ} \mathrm{C}$ to separate plasma from whole blood and the resulting plasma supernatants were carefully collected. All samples were immediately stored at $-80^{\circ} \mathrm{C}$, they were transported in a dry ice container to the laboratory.

Sample preparation: Sample preparation is a critical step to quantify small molecules in complex biological media and its quality can greatly influence the overall sensitivity and specificity of the subsequent analyses. Indeed, the highly abundant house-keeping proteins present in most biological fluids, in particular in plasma, semen, milk and saliva can mask detection of the less abundant bioactive peptides such as opiorphin.

After de-frosting at $4^{\circ} \mathrm{C}$, the biological samples were treated according to the following conditions: Acid-methanol extraction: To one volume sample four volumes of $0.1 \%$ trifluoroacetic acid (TFA, Sigma-France) in methanol were added at $4^{\circ} \mathrm{C}$, and the mixture immediately processed by vigorous stirring. This first step results in the precipitation and the elimination of high molecular weight proteins that are denatured in acid-methanol solutions. The soluble low molecular weight molecules (in particular opiorphin), found in the methanol phase, were separated from the precipitate by centrifugation at $4700 \mathrm{rpm}$ for $30 \mathrm{~min}$ at $4^{\circ} \mathrm{C}$ and were lyophilized at $-110^{\circ} \mathrm{C}$ for $48 \mathrm{~h}$. 
Saliva, tears and milk dried-extracts were reconstituted in 1 volume of pyrolyzed pure water corresponding to the initial volume of samples, processed by centrifuge at $4700 \mathrm{rpm}$ for $30 \mathrm{~min}$ at $4^{\circ} \mathrm{C}$; the resulting supernatants were conserved at $-80^{\circ} \mathrm{C}$ until subsequent procedures. In the case of sperm samples, dried-extracts were reconstituted in 0.2 times the initial volume to attain a $5 \mathrm{X}$ final concentration. In the case of urine samples, dried-extracts were reconstituted in 0.4 times the initial volume to achieve a $2.5 \mathrm{X}$ final concentration.

C18 Solid-phase Extraction: The acidified ( $\mathrm{HCl} 0.1 \mathrm{~N}$ final concentration) and clarified biological samples were applied to C18-SepPak cartridges (Waters, France) preconditioned with three successive cycles of methanol (Lichrosolv, Merck, France) and pure water and ultimately maintained in $0.1 \%$ TFA-water. After washing with $0.1 \%$ TFA-water $(5 \mathrm{ml})$, the analytes were eluted according to a multi-step gradient of methanol-water containing $0.1 \%$ TFA: $5 \%$, $-20 \%,-40 \%,-60 \%$ and $100 \%$ ( $5 \mathrm{ml}$ each). The successive fractions were collected at $4^{\circ} \mathrm{C}$, frozen at $-80^{\circ} \mathrm{C}$ and then lyophilized at $-110{ }^{\circ} \mathrm{C}$ for $48 \mathrm{~h}$. This extraction-purification step was critical in the case of plasma and milk. The dried-extracts of the fractions, 20 and $40 \%$ methanol, were reconstituted in pyrolyzed pure water and pooled in order to concentrate 50 fold the initial volume of plasma samples or 2.5 -fold the initial volume of milk samples.

Reverse phase C18-HPLC Chromatography: The resuspended dried-extracts, obtained during the procedures described above, were applied $(150 \mu \mathrm{l})$ to the top of the C18/RP-HPLC analytical column $(150 \times 4.5 \mathrm{~mm}$ Luna $5 \mu$ Phenomenex-France or ACE $5 \mu$ AIT-France) under TFA $0.1 \%$-water solvent equilibrium conditions. The various components were eluted and isolated according to their hydrophobic characteristics, in a 30-min linear gradient from $0 \%$ to $80 \%$ acetonitrile, containing $0.1 \%$ TFA (Lichrosol, Merck) at a $1 \mathrm{ml} /$ min flow rate (Surveyor HPLC system, ThermoScientific-France). The entire HPLC system was thermo-regulated at $12^{\circ} \mathrm{C}$. Each fraction $(1$ $\mathrm{ml}$ ) was collected and lyophilized at $-110^{\circ} \mathrm{C}$ for $48 \mathrm{~h}$. The determination of plasma opiorphin levels was achieved by analyzing each HPLCcollected fraction, from 15 to $26 \mathrm{~min}$, using the opiorphin ELISA. This HPLC purification step, that was critical in the case of the plasma samples, was also applied to the milk, semen and tear samples in order to determine the authentic presence of opiorphin molecule.

\section{Recovery}

Recovery was determined by adding tritiated or standard opiorphin to the biological samples in the same amounts as pre-established concentrations and processed as described above. The mean recovery was expressed as measured opiorphin concentration/added opiorphin concentration X 100\%. Recovery of the marker opiorphin-peptide alone (QR $\left[{ }^{3} \mathrm{H}\right]$ FSR) in SepPak fractions, eluted in $20 \%$ and $40 \%$ methanol, was $95 \%$. Recovery of the marker opiorphin-peptide alone (QR $\left[{ }^{3} \mathrm{H}\right]$ FSR) in eluting RP-HPLC fractions was $68 \%$. For HPLC, recovery was done every 7-10 sample injections after applying a stringent washing column procedure.

\section{Development of the ELISA - Opiorphin}

At the beginning of this study, none of the opiorphin detection system was commercially available. Thus, our expertise in the field of bioactive peptide isolation and quantification allowed us to develop and validate our own competitive ELISA system [18,21].

\section{principe and reagents}

Due to the small size of the opiorphin (693 Da), only a competitive type immuno-assay is applicable for the specific quantification of the peptide: competition between the measured free antigen and the coated or labelled antigen towards the anti-antigen antibodies [22]. Opiorphin QRFSR-peptide is not immunogenic therefore production of the antiopiorphin antibodies in the animal requires the injection of the peptide conjugated in a covalent manner to a carrier molecule. Anti-opiorphin antibody was generated after administration of the ovalbumin-[CO$\mathrm{NH}$ ]-YQRFSR immunogen (Genosphere Laboratories, France) to rabbits and a precise follow-up of the specific immune response (CovalAb biotechnologies, France). The polyclonal antibody, selected on the basis of its affinity for opiorphin, is referred to as 3RBF-SAB.

The specific immunological reaction was revealed using a universal system supplied by Pierce (ThermoScientific-France), namely, purified IgG immunoglobulin antibodies against rabbit IgG immunoglobulin conjugated to the horseradish peroxydase enzyme (HRP) followed by final addition of the chromogenic tetramethylbenzidine specific HRP substrate (Step UltraTMB-ELISA).

\section{method}

The opiorphin derivative selected for the coating on the microtitration plate (96-well-ImmunoPlate, Nunc-VWR) has the following sequence: Y- $\left[\mathrm{CH}_{2}\right]_{12}$-QRFSR peptide. Indeed, from previous tests it appears that the presence of the 12-polyethylene linker introduced between the tyrosine residue and the opiorphin peptide sequence facilitates the coating and the accessibility of the immobilized peptide to the antibody.

Optimized assay conditions are summarized as follows. For the coating, $40 \mathrm{ng}$ of the $\mathrm{Y}-\left[\mathrm{CH}_{2}\right]_{12}$-QRFSR peptide per $200 \mu \mathrm{l}$ coating buffer were added to individual wells (central 60 wells) on a 96well micro-titration plate and incubated overnight at $4^{\circ} \mathrm{C}$ with light shaking. In parallel, $100 \mu \mathrm{l}$ of standard (from $500 \mathrm{ng} / \mathrm{ml}$ to $1.9 \mathrm{ng} / \mathrm{ml}$ ) or samples that were serially diluted 2-fold with incubation buffer were pre-incubated in Matrix $0.75 \mathrm{ml}$ ScreenMates tubes (ThermoScientific) overnight at $10^{\circ} \mathrm{C}$ in the presence of $100 \mu \mathrm{l}$ anti-opiorphin antibody diluted at $1 / 80000$. The following day, after washing 5 times (microplate washer, BioTech-France) with washing buffer, $250 \mu \mathrm{l}$ of saturation buffer were added to the individual coated-wells and incubated at least $1 \mathrm{~h}$ at $20^{\circ} \mathrm{C}$. Then, after 5 -times washing, $100 \mu \mathrm{l}$ of the pre-incubated immunological reaction (anti-opiorphin antibody plus sample or reference peptide) were transferred on the coated and saturated microtitration plates and incubated $1.30 \mathrm{~h}$ at $10^{\circ} \mathrm{C}$ under humid atmosphere. After washing 5 times, $100 \mu$ lof the anti-rabbit IgG conjugated to HRP, diluted at $1 / 3000$, were added to each well and incubated $1 \mathrm{~h}$ at $20^{\circ} \mathrm{C}$. After incubation an ultimate wash was performed and $100 \mu$ of the HRP chromogenic substrate were added and incubated 30-45 min at $20^{\circ} \mathrm{C}$. Finally, the reaction was stopped, according to the manufacture's protocol, by adding $100 \mu \mathrm{l} 4 \mathrm{~N} \mathrm{H}_{2} \mathrm{SO}_{4}$. Plates were read at $450 \mathrm{~mm}$ with a micro-plate spectrophotometer (Infinite M200, Tecan-France) and the results were successively analyzed with Magellan (Tecan), Excel Microsoft and Prism GraphPad (La Jolia, USA) softwares.

The respective incubation buffers were the following: Coating buffer: potassium phosphate buffer at $100 \mathrm{mM}$ and $\mathrm{pH}$ 7.1; Saturation buffer: Tris buffer at $20 \mathrm{mM} \mathrm{pH} 7.5+150 \mathrm{mM} \mathrm{NaCl}+0.1 \%$ Tween $20+0.5 \%$ gelatin; First incubation buffer (anti-opiorphin antibody+sample or reference-peptide): Tris buffer at $200 \mathrm{mM}$ and $\mathrm{pH} 7.5+150 \mathrm{mM}$ $\mathrm{NaCl}+0.1 \%$ Tween $20+0.1 \%$ bovine serum albumine (BSA); Second incubation buffer (anti-rabbit IgG antibody conjugated to HRP): Tris buffer at $20 \mathrm{mM}$ and $\mathrm{pH} 7.5+150 \mathrm{mM} \mathrm{NaCl}+0.1 \%$ Tween $20+0.1 \%$ 
BSA and; Washing buffer: 1 tablet PBS-Sigma in $200 \mathrm{ml}$ pure pyrolyzed water+0.1\% tween 20 .

\section{Statistical Analysis}

A standard curve (8-9 concentration points in duplicate) was generated and fitted for each micro-titration plate and the opiorphin concentration of samples was determined using the regression equation obtained from each corresponding calibration curve. The individual values were expressed as the mean \pm SD for at least 2 determination points each in duplicate. Given the small number of subjects $(\mathrm{n}<30)$ nonparametric statistical analyzes were used and the results among each analyzed group expressed as the median concentration of opiorphin in $\mathrm{ng} / \mathrm{ml}$, the range and mean \pm SEM were also indicated in brackets. The significance of differences among groups was assessed by the Kruskal-Wallis one-way analysis of variance (KWT, a non-parametric method) to compare repeated measures in each group between several independent variables across the experimental conditions. When a significant difference among the groups was obtained, the MannWhitney post hoc test (MWT) was applied to compare each paired group. For all statistical evaluations, the level of significance was set at $P \leq 0.05$. All statistical analyses were carried out using the software StatView 5 statistical package (SAS, Institute, Inc., USA).

\section{Results and Discussion}

\section{Characteristics of the Elisa-Opiorphin}

The competitive-ELISA immunoassay for opiorphin is a reproducible and specific assay. The $\mathrm{IC}_{50}$ was determined at $30 \pm 9 \mathrm{ng} / \mathrm{ml}$ $($ mean $\pm \mathrm{SD})(50 \mathrm{pmol} / \mathrm{ml})$ for $n=9$ independent inter-day assays, each with 9 points of concentration (from 500 to $1.9 \mathrm{ng} / \mathrm{ml}$ ) in duplicate. The detection limit at $\mathrm{IC}_{85}$ is $2 \mathrm{ng} / \mathrm{ml}(3 \mathrm{pmol} / \mathrm{ml})$ of opiorphin QRFSRpeptide. The immunoassay is specific for opiorphin: the functionally related sialorphin QHNPR-peptide, as well as the QRFS, RFSR and FSR opiorphin-related fragments were not significantly recognized by the antibody (cross-reaction $\leq 1 \%$ ). Furthermore, a structural selectivity at the C-terminal part of the QRFSR-peptide for its binding affinity to the antibody was observed: substitution of the L-Arg5 by the stereoisomer D-Arg5 resulted in the loss of antibody recognition. Similarly, substitution at the N-terminal part of the peptide by a pyroGlul instead of Gln1, also inhibited antibody recognition. In contrast, the addition at the N-terminal position of the QRFSR peptide of amino acids such as Cys or Tyr did not alter antibody recognition.

A standard curve was generated for each intra-assay and the concentration of each sample was determined using the regression equation obtained from each corresponding calibration curve.

Given the small number of subjects $(n<30)$ the significance of differences among studied groups was assessed by non-parametric statistical analyzes. The results among analyzed groups were expressed as follows: median concentration of opiorphin (range, mean \pm SEM) in $\mathrm{ng} / \mathrm{ml}$.

\section{Secretion of opiorphin in human bloodstream}

We previously demonstrated that the functional homologue of human opiorphin, rat sialorphin, is an endocrine signal messenger of intercellular communication $[10,16,17,19]$. To determine whether opiorphin exhibits a similar secretory behavior we investigated and quantified its presence in the bloodstream of healthy male and female
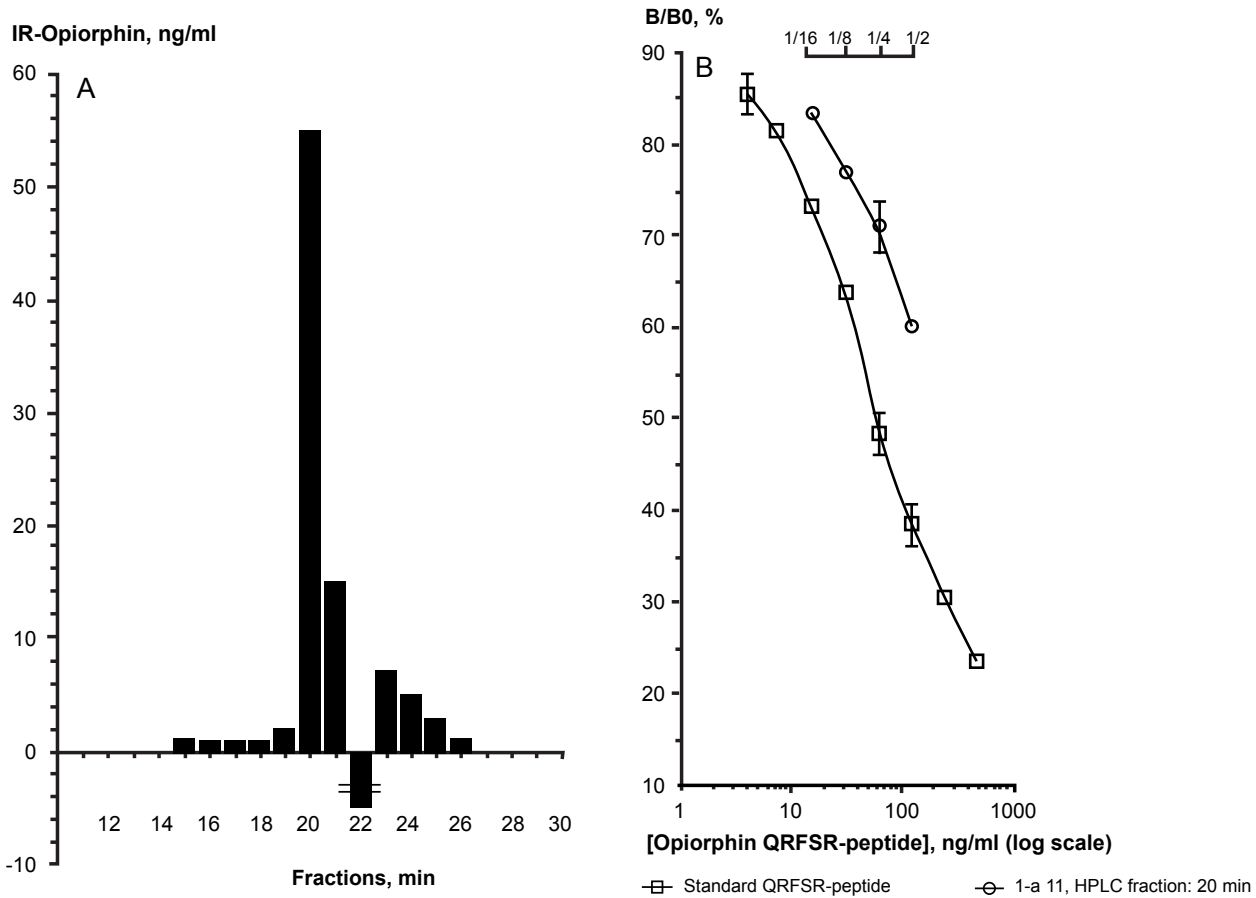

Figure 1: Analyses of human plasma by RP-HPLC and ELISA-Opiorphin. A. HPLC chromatography in tandem with ELISA-opiorphin detection of individual plasma extract. The plasma sample was extracted using a C18 solid-phase extraction procedure before loading onto a C18-ACE-HPLC column. After lyophilization each $1 \mathrm{~min}$ fraction was analyzed by ELISA-Opiorphin and the results expressed as concentration of immunoreactive (IR) opiorphin in ng/ml ( $Y$ axis) by HPLCfraction in $\min (X$ axis). B. Analysis of individual purified plasma sample using ELISA-Opiorphin method. Standard curve (open squares) relating QRFSR-peptide concentration in $\mathrm{ng} / \mathrm{ml}$ (log scale, $X$ axis) to the percentage of binding in the presence (B) of standard peptide / binding in the absence (B0) of the standard peptide (linear scale, $Y$ axis). Sample curve (open circles) relating serially diluted (2-fold) individual purified plasma sample to B/B0, \% response. Note that there is a parallel between the dose-response standard curve and the serial dilutions of the sample. Each point represents the mean \pm SD of duplicates. 
subjects. All plasma samples were submitted to a C18-solid phase extraction, according to the procedure described in Methods. Under such conditions, recovery of the marker QR $\left[{ }^{3} \mathrm{H}\right] \mathrm{FSR}$-opiorphin added to plasma samples was $68 \% \pm 2 \%, n=4$. Plasma extracts then underwent a purification step using RP-HPLC chromatography. The retention time of the reference opiorphin-peptide in the chromatographic system, using a C18-ACE column, is $20 \pm 0.5 \mathrm{~min}$ and the ELISA gave a $70 \pm 7 \%(n=10)$ recovery of the opiorphin QRFSR-peptide.

As shown in Figure 1a, HPLC elution profile of the human plasma extract, referenced 1a-11, demonstrates that immunoreactive opiorphin is detected at $20-21$ min retention time (Rt), identical to that of the reference peptide. This purification step separates opiorphin from the ELISA-interfering plasma molecular population (22 min Rt) which inhibits the competitive assay by nonspecifically enhancing the $\mathrm{B} 0$ values (Figure 1a). The immunoreactive curve obtained from successive dilutions of the HPLC fraction 20 min (1a-11, open circles, Figure $1 \mathrm{~b}$ ) is parallel to the dose-response curve corresponding to the reference QRFSR-peptide (open squares). This indicates that the antibody recognizes the natural opiorphin-peptide contained in human plasma extract with the same affinity as the synthetic pure peptide. The plasma level of opiorphin for this sample was established at $1.4 \pm 0.2$ $\mathrm{ng} / \mathrm{ml}$ for $\mathrm{n}=4$ points of determination (Figure $1 \mathrm{~b}$ ).

The median concentration of opiorphin in human plasma was $0.96 \mathrm{ng} / \mathrm{ml}$ (range 0.4-2.7 ng/ml, mean \pm SEM $1.07 \pm 0.12 \mathrm{ng} / \mathrm{ml}$ ) for 21 healthy adult male subjects and $0.55 \mathrm{ng} / \mathrm{ml}$ (range 0.2-3.4 ng/ml, mean \pm SEM $0.99 \pm 0.24 \mathrm{ng} / \mathrm{ml}$ ) for 16 healthy adult female subjects and $0.11 \mathrm{ng} / \mathrm{ml}$ (range 0.1-1.5 ng/ml, mean \pm SEM $0.28 \pm 0.18 \mathrm{ng} / \mathrm{ml}$ ) for 8 healthy pregnant women. The Kruskal-Wallis one-way analysis of variance (KWT) showed an overall heterogeneity in opiorphin plasma levels among the three groups, $\mathrm{H}=13.9, P=0.001$ (Figure 2). Although the median concentration of opiorphin appeared higher in male plasma, there was no significant difference between male and non-pregnant women paired groups. Only a tendency toward lower concentration in non-pregnant women emerged with a $\mathrm{P}$ value of 0.148 using the Mann Whitney U-Test (MWT). This is probably due to the larger range in the distribution of values among the female group. Despite this heterogeneity, a statistical significance emerges when comparing the 2 female groups, pregnant and non-pregnant women $(\mathrm{P}=0.002$ by $\mathrm{MWT})$. The physiological range of circulating opiorphin in young adult men (26 yr mean age) is similar to circulating sialorphin in conscious young adult male rats ( $8 \mathrm{wk}$ old) established by competitive RIA at $1-2 \mathrm{ng} / \mathrm{ml}$ under basal conditions [16]. We propose that, in analogy with its functional homologue in rat, human opiorphin is secreted as an endocrine messenger and circulates in the bloodstream to be delivered to a variety of distant NEP and APN-target tissues, where it induces a response.

The physiological median concentration of opiorphin in human urine samples was $7 \mathrm{ng} / \mathrm{ml}$ (range $4-27 \mathrm{ng} / \mathrm{ml}$, mean \pm SEM $8.3 \pm$ $1.5 \mathrm{ng} / \mathrm{ml}$ ) for $\mathrm{n}=15$ male subjects and $4 \mathrm{ng} / \mathrm{ml}$ (range 1-6, mean \pm SEM $3.9 \pm 0.4 \mathrm{ng} / \mathrm{ml}$ ) for $\mathrm{n}=15$ female subjects. Statistical analyses revealed that urinary excretion of opiorphin in males is significantly greater than in females $(\mathrm{P}<0.001$ vs. women by MWT). Four $( \pm 2)$ day sexual abstinence was requested before sampling, therefore, the possibility that part of the male urinary opiorphin comes from urethral semen contamination may be excluded (see the next chapter). Pharmacokinetic analyses in rats following iv administration of radiolabeled opiorphin $(\mathrm{QR}[3 \mathrm{H}] \mathrm{FSR}$-peptide) revealed that the native peptide, as well as its metabolites, are rapidly excreted, as soon as 1 min post-injection, from the blood compartment into the urine via renal glomerular filtration (unpublished observation by Rougeot C). Thus the significant difference between the rates of opiorphin urinary secretion in men compared to women could be attributed to a gender difference in its circulating systemic concentrations; however, as seen above, we failed to observe clear statistical differences in bloodstream opiorphin levels under our experimental conditions.

Taken together, our data suggest that, as in the case of rat sialorphin, human opiorphin expression and secretion is influenced by gender. Furthermore, the convergent data, notably the high heterogeneity in opiorphin plasma levels among females -which may be related to differences in the menstrual cycle-, the low rates of circulating opiorphin levels in the blood of pregnant women and the low rates of urinary opiorphin in females compared to males, suggest that the secretion of opiorphin in the female systemic compartment responds to its own physiological hormonal status, notably during menstrual cycle and gestation. By this way, it is of interest that, the NEP-cell surface target for opiorphin exhibits different expression patterns during menstruation and progesterone induces transcription of the NEP gene by the coordinated action of multiple androgen responsive elements $[23,24]$. Unfortunately, for our study, the specific phase in the menstrual cycle was not allocated when blood collection.

\section{Secretion of opiorphin in human semen}

We previously demonstrated that the functional homologue of human opiorphin, rat sialorphin, is expressed in prostate gland $[15,18]$. Therefore, in the present study, we analyzed the concentration of opiorphin in human semen obtained from healthy donors.

In order to measure the biological parameters of the seminal fluid of donors, in particular spermatozoa motility and vitality, the seminal fluids were collected in tubes containing a limited cocktail of peptidase. A comparative study was then conducted to establish the best conditions for opiorphin extraction. As shown in Figure 3a, treatment

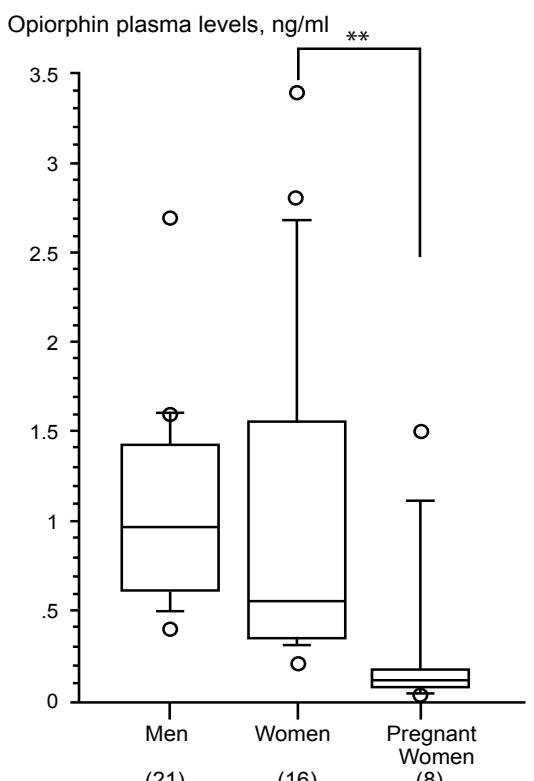

Figure 2: Box plot representations of plasma opiorphin levels in healthy young men $(n=21)$, women $(n=16)$ and pregnant women $(n=8)$. Single individual values below the $10^{\text {th }}$ or above the $90^{\text {th }}$ percentile are represented as open circles. The box intersecting line represents the median and the box upper and lower limits represent the $75 \%$ and $25 \%$ percentile, respectively. ${ }^{* *} P<0.01$ by MWT; (n) number of subjects. 
of human semen samples with EDTA (1mM final concentration) prior to acid-methanol extraction is a crucial step for opiorphin quantification, with values 6-10 times higher than those in the absence of the chelating agent $(P=0.002$ by MWT). This suggests that opiorphin in seminal fluid is mainly associated in a molecular complex, involving a cation-mineral element, potentially $\mathrm{Zn}^{++}$ion, a prostate biochemical marker that is found in semen at $55-420 \mathrm{mg} / \mathrm{ml}$ concentration range in fertile men [25]. Under these extraction conditions, recovery of the opiorphin-peptide marker, added to the sample before acid-methanol extraction, was $70 \%$.

Using the RP-HPLC chromatographic system with a C18-Luna column, the retention time of the reference opiorphin-peptide is 22-23 min. Fractionation coupled to ELISA analysis of two semen extracts, referenced 3a-13 and 3b-02 (Figure 3b), revealed that seminal immuno-reactive opiorphin is primarily eluted at 22-23 min retention time (Rt). This peak is also active as it inhibited, by at least $50 \%$, membrane-bound human NEP activity (method described in ref. 53). A second hydrophobic immunoreactive population $(\mathrm{Rt}=27 \mathrm{~min})$ was also observed that can represent up to $50 \%$ of the immunoreactive opiorphin. This molecular population could correspond to an opiorphin oligomer complexed via a metal cation such as seminal $\mathrm{Zn}^{++}$ ion that was not completely dissociated during the treatment, prior to extraction procedure, by the EDTA chelating agent. Interestingly, there was a quantitative difference between the chromatographic profiles of the two samples; sample 3a-13 is an extract of whole semen from the fertile group while the extract $3 \mathrm{~b}-02$ consists only of prostatic secretions belonging to the infertile group.

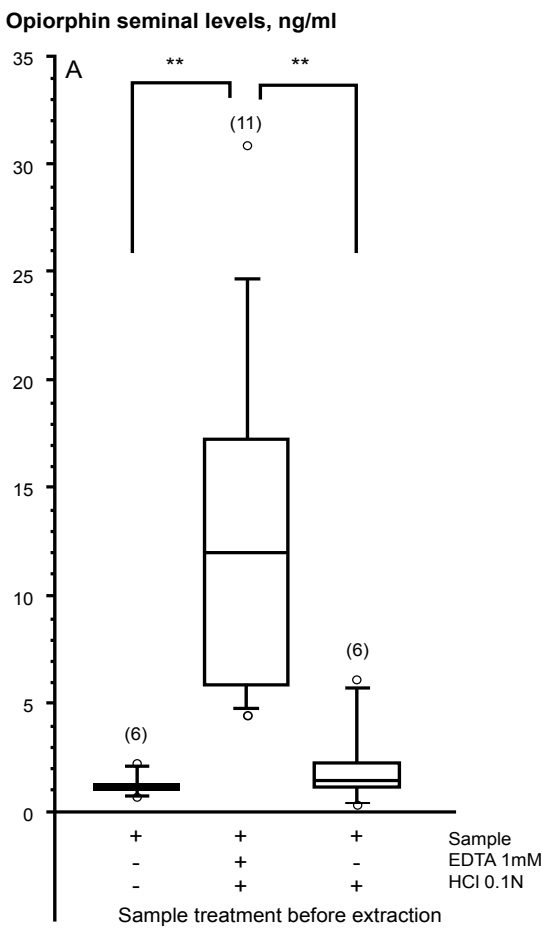

The physiological median concentration of opiorphin in semen from normozoospermic healthy human donors was $12.0 \mathrm{ng} / \mathrm{ml}$ for 11 subjects (range 4.5 to 30.9 , mean \pm SEM $12.9 \pm 2.4 \mathrm{ng} / \mathrm{ml}$ or $43.6 \pm$ $10.2 \mathrm{ng} /$ ejaculate volumes, Figures $3 \mathrm{a}$ and 4 ). Interestingly, opiorphin was also detected in the semen of patients with congenital bilateral absence of the vas deferens inducing infertility, although testicular spermatogenesis is normal. The opiorphin levels (median at $3.5 \mathrm{ng} /$ $\mathrm{ml}$, range from 3 to $8.5 \mathrm{ng} / \mathrm{ml}$, mean \pm SEM $4.7 \pm 1.0 \mathrm{ng} / \mathrm{ml}, 5.8 \pm$ $1.6 \mathrm{ng} /$ ejaculate volume, $n=5$, Figures $3 \mathrm{~b}$ and 4 ) of these patients were lower than those of normozoospermic donors. However, the presence of opiorphin in the semen of CBAVD patients demonstrates that about $15 \%$ of the peptide secretion in the seminal fluid originates from the prostate glands.

Database searches of the human transcriptome reveal that the $P R O L 1$ gene is expressed in the male reproductive system, in particular in testis and prostate glands as well as in epididymis. These data, provided by affymetrix GeneChips technology, should explain the higher opiorphin values obtained in healthy donors compared to CBAVD patients. Furthermore, it has been reported that the level of expression of the PROL1 gene in corpora cavernosa tissue samples of men with erectile dysfunction (ED, associated with diabetic or nondiabetic aetiology) is severely down-regulated compared to normal volunteers [26].

Testes contain a great variety of different bioactive peptides that play a role in the local control of gonadal development and also function through autocrine/paracrine mechanisms [27]. All the components of the endogenous opioid system, which includes opiorphin, are
IR-Opiorphin, ng/ml

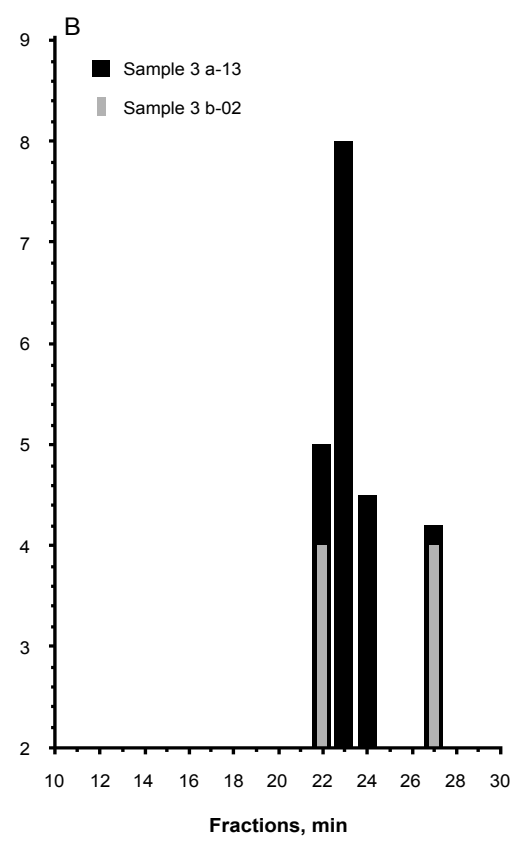

Figure 3: Analyses of healthy and CBAVD human semen by RP-HPLC and ELISA-Opiorphin. A. Box plot representations of sperm opiorphin levels in healthy young men under different extraction conditions. Single individual values below the $10^{\text {th }}$ or above the $90^{\text {th }}$ percentile are represented as open circles. The box intersecting line represents the median and the box upper and lower limits represent the $75 \%$ and $25 \%$ percentile, respectively. ** $P<0.01$ by MWT; $(n)$ number of subjects. B. HPLC chromatography-tandem ELISA-opiorphin detection of two semen extracts. Both samples, 3a-13 (healthy donor) and 3b-02 (CBAVD patient) were extracted by an acid-methanol procedure prior to loading onto a C18-Luna-HPLC column. After lyophilization each 1 min fraction was analyzed by ELISA-Opiorphin and the results expressed as concentration of immunoreactive (IR) opiorphin in ng/ml ( $Y$ axis) by HPLC-fraction in min ( $X$ axis). 
present in the male genital tract and are implicated in the control of sperm motility-regulating levels of enkephalin endogenous opioid peptides in seminal fluid [28-31]. The presence of both membranebound targets of opiorphin (AP-N and NEP ectoenkephalinases) and of enkephalins (opioid receptors) in sperm cells [29-31] is consistent with the important level of opiorphin and enkephalins in the seminal fluid and support the idea that the inhibition of enkephalin-degrading ectopeptidases by opiorphin could help maintain sperm motility by increasing enkephalin bioavailability. The data taken together suggest that the distribution of opiorphin in the human reproductive tract mediates male sexual function, as previously demonstrated for sialorphin in rats [12-14].

\section{Secretion of opiorphin in human milk}

Rat sialorphin is expressed in the mammary glands of gestational female rats, is secreted into the milk of lactating rats and is present in the stomach of newborn rats (unpublished observations by Rougeot C). In order to determine whether opiorphin is secreted in human milk we analyzed its distribution in samples from healthy lactating women $(n=7)$ at $3-5 \mathrm{wk}$ post-delivery period.

A C18-solid phase (SepPak cartridge) extraction procedure was applied for each sample to eliminate the ELISA-interfering milk components. As in the case of the seminal fluid, previous treatment of milk samples by EDTA ( $1 \mathrm{mM}$ final concentration) before extraction is a crucial step to obtain quantifiable milk opiorphin, with values at least 2-3 times higher than those in absence of the chelating agent. Using these extraction conditions, recovery of the opiorphin peptide marker was $97 \%$. As shown in Figure 5a, the immunoreactive curve obtained from successive dilutions of the milk sample extract, referenced 2-06, is parallel to the dose-response curve corresponding to the reference QRFSR-peptide. The antibody, therefore, recognizes

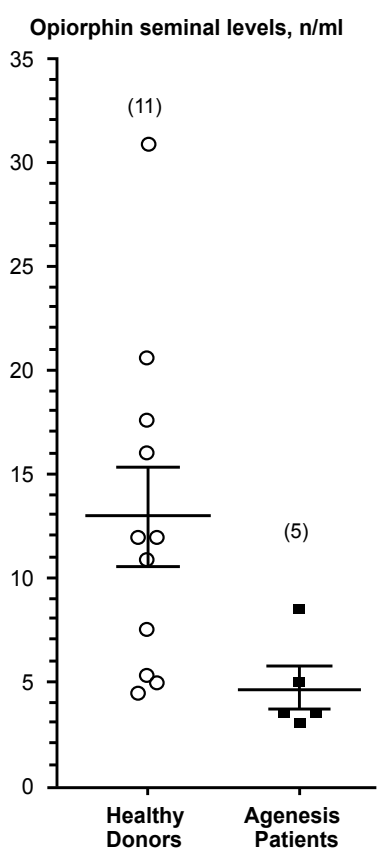

Figure 4: Dot plot representations of semen opiorphin levels in healthy donors and CBAVD patients. Each individual opiorphin value is represented by an open circle for healthy donors $(n=11)$ and by a black square for CBAVD patients $(n=7)$. The mean \pm SEM for both groups are represented. the milk peptide with the same affinity as the synthetic pure peptide. RP-HPLC fractionation using a C18-ACE column and ELISA analysis of the same milk extract showed that immunoreactive opiorphin is detected at 20-21 min retention time (Rt), which coincides with the reference peptide. As in the case of the semen samples, an additional major immuno-reactive peak at 25-26 Rt was also observed. This hydrophobic molecular population corresponds to a metal cationbinding opiorphin oligomer, because treatment by a strong chelating agent, DTPA (diethylenetriaminepenta-acetic acid, Sigma) at $16 \mathrm{mM}$ final concentration, prior to HPLC chromatography, completely restored the native opiorphin product that is eluted at 20-21 min $\mathrm{Rt}$ (Figure 5b).

The physiological median concentration of opiorphin in milk was $8.3 \mathrm{ng} / \mathrm{ml}$ for a range of 3 to $23 \mathrm{ng} / \mathrm{ml}$ and mean \pm SEM of $10.7 \pm 2.4 \mathrm{ng} /$ $\mathrm{ml}$, for 7 subjects (Figure 6). Interestingly, we observed that opiorphin QRFSR-peptide circulates in milk, as in the seminal fluid, as a soluble complex that interacts with metal cation. Human opiorphin binding to metal cations has been reported by Kotynia et al. [32] and also reported by us for rat sialorphin [16]. Thus, opiorphin is distributed in milk under 2 forms: a free form and a major mineral-binding molecular species which help prevent peptide degradation and/or facilitate transport or it may function as carrier for different minerals, in particular calcium.

Milk is a major source of biologically active peptides with opioid or peptidase inhibitory activities that function as modulators of various regulatory processes in neonatal development, ranging from gastrointestinal functions to centrally and/or peripherally mediated neuroendocrine functions after crossing the gut-blood barrier [33-36] Affymetrix GeneChips technology provided tissue expression data for the PROL1 gene, encoding opiorphin precursor, which in the female reproductive system is expressed in addition to mammary gland in ovary, uterus and also amniotic fluid. NEP and AP-N membranebound cell surface peptidases, which are targets for opiorphin, are also expressed by different cell populations of the human breast, ovarian granulosa, endometrial and chorionic placental cells, in addition to fetal membranes [28,37-39]. These findings suggest that opiorphin may play a local physiological regulatory role in follicular growth, ovulation, embryo implantation processes and maternal-fetal interface by controlling the local concentration of NEP and/or AP-Nsensitive functionally active regulatory peptides. Further studies will be necessary to support our hypothesis that opiorphin participates in the regulation of reproductive physiology, operating at multi-states as a local exocrine and paracrine/autocrine regulator and a distal endocrine regulator in female reproduction, pregnancy and fetal development as well as in parturition and the post-natal lactation period for newborn development.

\section{Secretion of opiorphin in human tears}

In 1996, Dickinson et al described the expression of the PROL1 gene precursor in human lachrymal glands [20]. Here we investigated the presence of opiorphin, the mature secretory peptide product of the PROL1 gene, in the tears of male and female healthy volunteers. RP-HPLC fractionation in tandem with ELISA analysis of the female tear extracts showed that immunoreactive opiorphin is detected at the retention time of the reference QRFSR-peptide, confirming that opiorphin circulates in tears. Analyses of all the human tear samples collected from healthy females showed that the median physiological concentration of opiorphin is $220 \mathrm{ng} / \mathrm{ml}$ (range 2 to $1109 \mathrm{ng} / \mathrm{ml}$, mean \pm SEM $296 \pm 77 \mathrm{ng} / \mathrm{ml}, n=15$ ), while that of healthy men ranges from 2 to $183 \mathrm{ng} / \mathrm{ml}(n=9)$. Opiorphin levels of male tears were, for most individuals, inferior to the detection limit ( 6 out of 9 subjects $\leq 2 \mathrm{ng} / \mathrm{ml}$ ) 
and the tear volume collected was in general very low. So, opiorphin is secreted in tears at the highest physiological rates, demonstrating that lachrymal glands are the tissue of major expression and secretion of PROL1 gene products.

Tears, a critical body fluid of the eye, contain a large variety of molecules including peptides, which are primarily secreted by the lachrymal glands. Components of tear fluid contribute to the defense system of the eye and the functional ocular surface-central nervous system-lachrymal gland neural network is crucial in maintaining ocular surface health and homeostasis. Proenkephalin A-derived peptides, Met5- and Leu5-enkephalins, and their cognitive receptors are present and the physiological significance of endogenous enkephalins in lachrymal function, as an inhibitor of lachrymal secretion, is reported [40-42]. The present study demonstrates the presence of lachrymal tissue-specific expression and secretion of opiorphin in tear fluid from healthy volunteers. A role for opiorphin in modulating lachrymal fluid homeostasis by increasing enkephalin bioavailability in the case, for example, of certain causes of epiphora could be evoked.

We propose a paracrine and/or autocrine role of opiophin in the lachrymal system and at the ocular surface. Further studies will provide new clues for a molecular understanding of lachrymal gland function and regulation.

\section{Secretion of opiorphin in human saliva}

Opiorphin from human saliva has been well characterized at both molecular and functional levels [1]. Here, in a comparative study, we examined the secretory levels of opiorphin in salivary fluids of healthy young adult men and women, including pregnant women.

Statistical analysis of human saliva samples collected from healthy young adult males of $26 \pm 6 \mathrm{yr}$ mean age, showed that the median concentration of opiorphin is $53 \mathrm{ng} / \mathrm{ml}$ (range 7-196 ng/ml, mean \pm SEM $69 \pm 11 \mathrm{ng} / \mathrm{ml}$ ) for 23 subjects under basal conditions. Under conditions of chemical stimulation of salivation, by applying a drop of diluted lemon to the mouth floor, the median opiorphin concentration was $163 \mathrm{ng} / \mathrm{ml}($ range $80-1057 \mathrm{ng} / \mathrm{ml}$, mean \pm SEM $335 \pm 83 \mathrm{ng} / \mathrm{ml}$ ) for 18 subjects. Salivary secretion of opiorphin in males is significantly increased under conditions of salivation stimulation by citric acid $(P$ $=0.0001$ vs. basal by MWT, Figure 7). Saliva samples collected from healthy females showed a median concentration of opiorphin of $30 \mathrm{ng} /$ $\mathrm{ml}$ (range 6-219 ng/ml, mean \pm SEM $61 \pm 23 \mathrm{ng} / \mathrm{ml}$ ) for 10 subjects under basal conditions, and of $158 \mathrm{ng} / \mathrm{ml}$ (range $24-1091 \mathrm{ng} / \mathrm{ml}$, mean \pm SEM $213 \pm 76 \mathrm{ng} / \mathrm{ml}$ ) for 13 subjects under saliva stimulating conditions. Statistical analyses demonstrated that salivary secretion of opiorphin in women is significantly increased under conditions of citric acid stimulation ( $\mathrm{P}=0.006$, Figure 7$)$ compared to resting conditions. Thus, at baseline and under chemical stimulated conditions, the levels of opiorphin in male compared with female saliva were not significantly different.

It is interesting to note that the rate of rat sialorphin salivary secretion under stimulated conditions of the sympathetic nervous system that innervates the salivary glands is similar to human opiorphin salivary secretion under conditions of local chemical stimulation of the mouth nerve endings. However, the secretion rate of salivary sialorphin in male rats is significantly higher than that of female rats $[17,18]$, while the significant increase in opiorphin following chemical stimulation is not sex-linked ( $P=0.289$ by MWT). Strikingly, the level of salivary opiorphin for one healthy female volunteer was high, both in basal $(1072 \mathrm{ng} / \mathrm{ml})$ and in stimulated conditions $(1637 \mathrm{ng} / \mathrm{ml})$. The clinical data associated with this sample revealed that the subject was treated

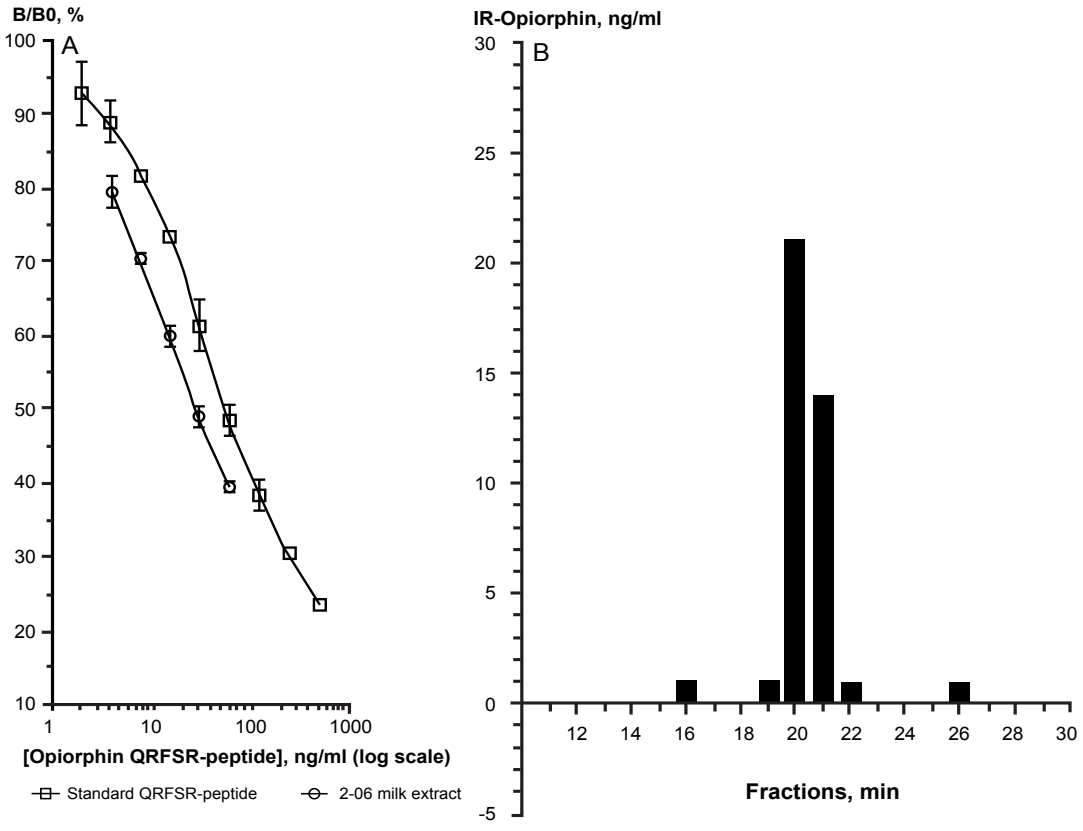

Figure 5: Analyses of human milk by RP-HPLC and ELISA-Opiorphin. A. Analysis of individual milk samples using the ELISA-Opiorphin method. Standard curve (open squares) relating opiorphin concentration in $\mathrm{ng} / \mathrm{ml}$ (log scale, $X$ axis) to the B/B0 (the percentage of binding in the presence (B) of standard peptide / binding in the absence (B0) of the standard peptide: linear scale, $Y$ axis) and sample curve (open circles) relating serially diluted (2-fold) individual purified milk sample (2-06) to the B/B0, \% response. Note that there is a parallel between the dose-response standard curve and serial dilutions of the sample. Each point represents the mean \pm SD of duplicates. B. HPLC chromatography in tandem with ELISA-opiorphin detection of individual milk extracts. The milk sample (2-06) was extracted by the $\mathrm{C} 18$ solid-phase extraction procedure and the dried extract was treated with DTPA, 16 mM final concentration, prior to loading onto the C18-ACE-HPLC column. After lyophilization each $1 \mathrm{~min}$ fraction was analyzed by ELISA-Opiorphin and the results expressed as concentration of immunoreactive (IR) opiorphin in $\mathrm{ng} / \mathrm{ml}$ ( $\mathrm{Y}$ axis) by HPLC-fraction in min ( $\mathrm{X}$ axis). 


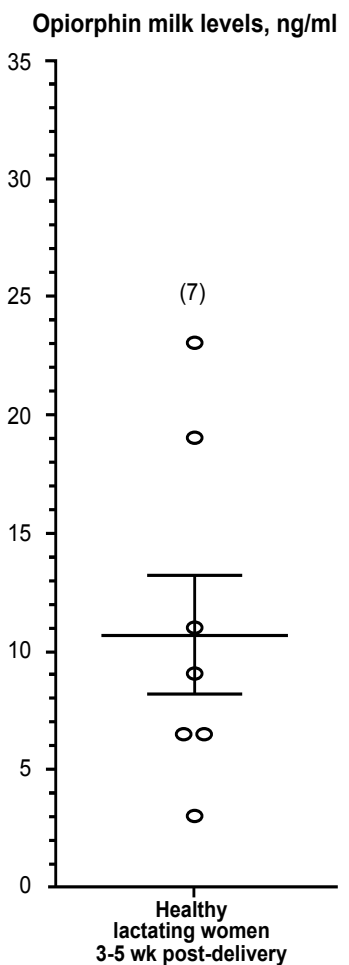

Figure 6: Dot plot representations of milk opiorphin levels in healthy lactating women at 3-5 wk post-delivery. Each individual opiorphin value is represented by open circle for 7 samples. The mean \pm SEM is represented.

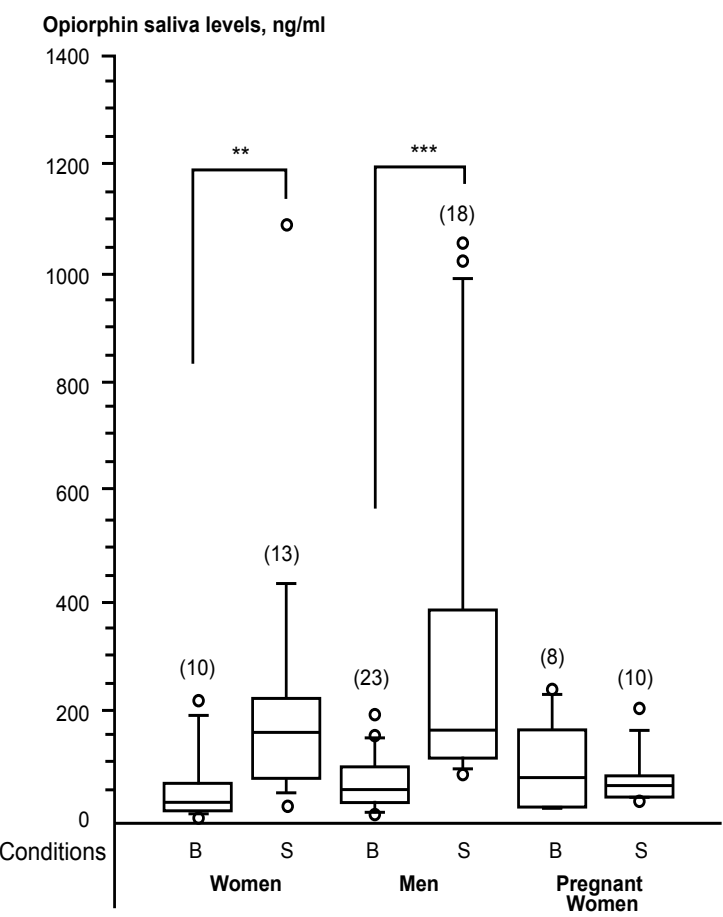

Figure 7: Box plot representations of salivary opiorphin levels in healthy young men, women and pregnant women under basal (B) and stimulated (S) salivary secretion conditions. Single individual values below the $10^{\text {th }}$ or above the $90^{\text {th }}$ percentile are represented as open circles. The box intersecting line represents the median and the box upper and lower limits represent the $75 \%$ and $25 \%$ percentile, respectively. ${ }^{* \star} P<0.01$; ${ }^{* \star \star} P<0.001$ by MWT; $(n)$ number of subjects, B basal conditions, $\mathrm{S}$ stimulated conditions. with thyroid hormones. Consequently, the sample was excluded from statistical analyses.

The saliva samples collected from sixth month pregnant women showed a median concentration of opiorphin of $78 \mathrm{ng} / \mathrm{ml}$ (range 20-237, mean \pm SEM $99 \pm 29 \mathrm{ng} / \mathrm{ml}$ ) for 8 subjects under resting conditions, which is not significantly different from that obtained among non-pregnant women of the same age. In contrast, under stimulated conditions the median level of salivary opiorphin was $60 \mathrm{ng} /$ $\mathrm{ml}$ (range $34-205 \mathrm{ng} / \mathrm{ml}$, mean \pm SEM $77 \pm 16 \mathrm{ng} / \mathrm{ml}$ ) for 10 subjects. Thus, the chemical stimulation of saliva secretion actually causes a slight decrease in opiorphin levels in the pregnant female population. In contrast then to the non-pregnant female population studied, the secretory opiorphin rates in stimulated saliva is significantly lower $(\mathrm{P}=0.028$ vs. non-pregnant women by MWT, Figure 7$)$.

Opiorphin quantification in human saliva using liquid chromatography in tandem with mass spectrometry (MS) was recently reported by Brkljačić et al. [43]. In their report, opiorphin concentration in the whole saliva of 14 young healthy individuals $(23 \pm 3 \mathrm{yr})$ is $9.4 \pm$ $5.4 \mathrm{ng} / \mathrm{ml}$ ( $n=8$ females) and $7.2 \pm 4.6 \mathrm{ng} / \mathrm{ml}$ ( $n=6$ males), which is 7 times lower than our measured basal values. Several possibilities could explain such important differences: - the methodology employed: mass spectrometry vs. immunoassay; - the conditions of saliva collection: absence of peptidase inhibitors for LC-MS/MS analyses and - the conditions of sample preparation: absence of extraction procedure for LC-MS/MS analyses. Moreover, using SELDI-TOF MS analysis we previously noted that in the presence of TFA, the reference synthetic QRFSR-peptide, as well as purified opiorphin from human saliva, present two molecular masses, 690 and 769. Furthermore, QRFSRpeptide was found in the saliva in two active forms Gln1- and Glp1RFSR with molecular masses of 690 and 665 respectively [1]. All these active opiorphin-related derivatives are invisible to MS/MS detection because of their different masses.

Affymetrix GeneChips technology provided tissue expression data for the PROL1 gene encoding opiorphin precursor, which in the oral cavity is expressed in parotid, submandibular and sublingual gland substructures only in adult stages, including early adulthood (from $19 \mathrm{yr}$ ). These developmental stage data coincide perfectly with those obtained previously for the SMR1RAT1 gene encoding sialorphin precursor. However, sialorphin expression in rat salivary glands is limited to the submandibular glands, which does not seem the case in humans, the contribution of each gland in the production of saliva opiorphin has yet to be determined.

Salivary opiorphin may act on its membrane-bound target sites, i.e., NEP and/or AP-N ectopeptidases, that are present in oral sites as well as in the lower segments of the digestive axis and control salivary concentrations of circulating NEP- and/or AP-N-sensitive regulatory peptides [44-46] and/or modulate colonic motility via an indirect action on enkephalin-dependent opioid receptors [8]. Salivary opiorphin may also be absorbed and enter the circulation to mediate endocrine and behavioral effects [1].

\section{Conclusion}

The quantitative profile of opiorphin secretion in biological fluids of male and female volunteers is summarized in Table 1. Our findings, associated with human transcriptome data, demonstrate that the $P R O L 1$ gene encoding opiorphin precursor is expressed and translated in the reproductive system, notably the testis, epididymis and prostate in men and in the mammary glands of women, in the gastrointestinal 
Citation: Dufour E, Villard-Saussine S, Mellon V, Leandri R, Jouannet P, et al. (2013) Opiorphin Secretion Pattern in Healthy Volunteers: Gender Difference and Organ Specificity. Biochem Anal Biochem 2: 136. doi:10.4172/2161-1009.1000136

Page 10 of 11

\begin{tabular}{|c|c|c|c|}
\hline & \multicolumn{2}{|c|}{ Opiorphin levels, ng/mI Median (range) Number of subjects } \\
\hline Subjects $26 \pm 6$ yr mean age & Men & $0.55(0.2-3.4) n=16$ \\
\hline BioFluids & & $4(1-6) n=15$ \\
\hline Bloodstream & $0.96(0.4-2.7) n=21$ & \\
\hline Urines & $7(4-27) n=15$ & \\
\hline Semen Healthy donors & $12(4.5-30.9) n=11$ & $8.3(3-23) n=7$ \\
\hline Semen CBAVD & $3.5(3-8.5) n=5$ & $220(2-1109) n=15$ \\
\hline Milk 2-3 week post-delivery & & $30(6-219) n=10$ \\
\hline Tears & $(<2-183) n=9$ & $158(24-1091) n=13$ & \\
\hline Saliva Basal conditions & $53(7-196) n=23$ & \\
\hline Saliva Stimulated conditions & $163(80-1057) n=18$ & $78(20-237) n=8$ \\
\hline
\end{tabular}

Table 1: Summary of opiorphin values in biological fluids of male and female volunteers.

system, notably in the salivary glands as well as in the ocular system, notably in the lachrymal glands. In these tissues, opiorphin precursor is selectively processed, in a manner similar to the classic maturation pathway of peptide-hormone precursors, to give rise to a mature peptide product, the opiorphin pentapeptide. Mature opiorphin peptide can then be secreted from intracellular stores into the extracellular space, in response to specific stimuli and transported within local fluids, such as semen, milk, tears and saliva and within the bloodstream to exert paracrine, endocrine and/or neuroendocrine actions on local and distal target cells.

Opiorphin is a natural inhibitor of enkephalin-inactivating ectopeptidases in humans. Based on its known biological functions, endogenous opiorphin could facilitate adaptative responses to stressful or threatening environmental stimuli by potentiating enkephalindependent antinociceptive response via activation of endogenous opioid-dependent pathways [1,7]. Here, we presented a physiological biomedical research program and now it is of interest to identify different human pathological states that up-regulate or down-regulate the levels of circulating opiorphin peptide. In this context, we have already established a biomedical research protocol in collaboration with Dr. Yves Boucher to determine the secretion profile of opiorphin in patients suffering from stomatodynia, also called "mouth burning syndrome" which is a chronic oral mucosal pain with uncertain ethiopathogenesis [47].

Interestingly, we found that in vivo, in particular in milk and seminal fluids, opiorphin circulates under two forms: a free form and a cation mineral-binding molecular form. In vitro opiorphin binding ability for metal cation has been reported [32]. An opiorphin-mineral complex could prevent peptide degradation and/or facilitate transport or could modify peptide bioactivity. To discriminate between these different hypotheses it will be important to define the metabolic halflife of the complex compared to free opiorphin (metabolic half-life at 4-5 min in human plasma) by ex vivo, pharmacokinetic and metabolic studies as well as by determining its inhibitory potency on human NEP and AP-N metallo-peptidases by in vitro FRET-based enzyme assays [48].

Affymetrix GeneChip technology provided evidence that the $P R O L 1$ gene, encoding opiorphin precursor, is expressed in human brain, in particular in a key output structure of the basal ganglia in the globus pallidus that contains dense enkephalinergic fibers. Opiorphin pentapeptide modulation of enkephalinergic pathways in striatopallidal projection neurons may be of functional importance, in particular in the regulation of central pain perception and mood-related states. Therefore, it is of great interest to explore whether opiorphin is present in the cerebrospinal fluid of healthy volunteers and to determine its secretory processing in the central nervous system.

\section{Acknowledgement}

We would like to thank the contributions to the present project of $\mathrm{Pr}$. Y. Dumez and collaborators (Centre of Obstetrics of Necker-Enfants Malades hospital, Paris) for their inputs on establishing the clinical research program and $\mathrm{C}$. Ottone who was in charge of sample processing, cryopreservation and distribution and traceability at all steps. The present address of R. LEANDRI: Groupe d'activité de Médecine de la Reproduction, CHU de Toulouse, 330 Avenue de Grande Bretagne, 31059 Toulouse cedex 9 .

This work was in large part supported by funding sources from BioRad laboratories and from the "Direction de la Valorisation et des Partenariats Industriels" and "Dons et Mécénat d'entreprises" Institut Pasteur. No conflicts of interest, financial or otherwise, are declared by the author(s).

\section{References}

1. Wisner A, Dufour E, Messaoudi M, Nejdi A, Marcel A, et al. (2006) Human Opiorphin, a natural antinociceptive modulator of opioid-dependent pathways. Proc Natl Acad Sci U S A 103: 17979-17984.

2. Rougeot C, Messaoudi M (2007) [Identification of human opiorphin, a natura antinociceptive modulator of opioid-dependent pathways]. Med Sci (Paris) 23: 37-39.

3. Tóth F, Tóth G, Benyhe S, Rougeot C, Wollemann M (2012) Opiorphin highly improves the specific binding and affinity of MERF and MEGY to rat brain opioid receptors. Regul Pept 178: 71-75.

4. König M, Zimmer AM, Steiner H, Holmes PV, Crawley JN, et al. (1996) Pain responses, anxiety and aggression in mice deficient in pre-proenkephalin. Nature 383: 535-538.

5. Nieto MM, Guen SL, Kieffer BL, Roques BP, Noble F (2005) Physiological control of emotion-related behaviors by endogenous enkephalins involves essentially the delta opioid receptors. Neuroscience 135: 305-313.

6. Javelot H, Messaoudi M, Garnier S, Rougeot C (2010) Human opiorphin is a naturally occurring antidepressant acting selectively on enkephalin-dependent delta-opioid pathways. J Physiol Pharmacol 61: 355-362.

7. Rougeot C, Robert F, Menz L, Bisson JF, Messaoudi M (2010) Systemically active human opiorphin is a potent yet non-addictive analgesic without drug tolerance effects. J Physiol Pharmacol 61: 483-490.

8. Tian XZ, Chen J, Xiong W, He T, Chen Q (2009) Effects and underlying mechanisms of human opiorphin on colonic motility and nociception in mice. Peptides 30: 1348-1354.

9. Yang QZ, Lu SS, Tian XZ, Yang AM, Ge WW, et al. (2011) The antidepressantlike effect of human opiorphin via opioid-dependent pathways in mice. Neurosci Lett 489: 131-135.

10. Rougeot C, Messaoudi M, Hermitte V, Rigault AG, Blisnick T, et al. (2003) Sialorphin, a natural inhibitor of rat membrane-bound neutral endopeptidase that displays analgesic activity. Proc Natl Acad Sci U S A 100: 8549-8554.

11. Rougeot $C$ (2004) From the gene to candidate drug. The discovery of sialorphin using inverse pharmacology. BIOforum Europe 5: 52-55

12. Messaoudi M, Desor D, Nejdi A, Rougeot C (2004) The endogenous androgenregulated sialorphin modulates male rat sexual behavior. Horm Behav 46: 684 691

13. Davies KP, Tar M, Rougeot C, Melman A (2007) Sialorphin (the mature peptide 
Citation: Dufour E, Villard-Saussine S, Mellon V, Leandri R, Jouannet P, et al. (2013) Opiorphin Secretion Pattern in Healthy Volunteers: Gender Difference and Organ Specificity. Biochem Anal Biochem 2: 136. doi:10.4172/2161-1009.1000136

Page 11 of 11

product of Vcsa1) relaxes corporal smooth muscle tissue and increases erectile function in the ageing rat. BJU Int 99: 431-435.

14. Tong Y, Tiplitsky SI, Tar M, Melman A, Davies KP (2008) Transcription of G-protein coupled receptors in corporeal smooth muscle is regulated by the endogenous neutral endopeptidase inhibitor sialorphin. J Urol 180: 760-766.

15. Rosinski-Chupin I, Huaulmé JF, Rougeot C, Rougeon F (2001) The transcriptional response to androgens of the rat VCSA1 gene is amplified by both binary and graded mechanisms. Endocrinology 142: 4550-4559.

16. Rougeot C, Vienet R, Cardona A, Le Doledec L, Grognet JM, et al. (1997) Targets for SMR1-pentapeptide suggest a link between the circulating peptide and mineral transport. Am J Physiol 273: R1309-1320.

17. Rougeot C, Rosinski-Chupin I, Rougeon F (1998) From the gene for the submandibular rat1 protein (SMR1) precursor to receptor sites for SMR1 mature peptides: Novel genes and hormones in salivary glands. Biomedical Reviews, Bulgarian-American Center, Varna, Bulgaria.

18. Rougeot C, Rosinski-Chupin I, Njamkepo E, Rougeon F (1994) Selective processing of submandibular rat 1 protein at dibasic cleavage sites. Salivary and bloodstream secretion products. Eur J Biochem 219: 765-773.

19. Rougeot C, Rosinski-Chupin I, Mathison R, Rougeon F (2000) Rodent submandibular gland peptide hormones and other biologically active peptides. Peptides 21: 443-455.

20. Dickinson DP, Thiesse M (1996) cDNA cloning of an abundant human lacrimal gland mRNA encoding a novel tear protein. Curr Eye Res 15: 377-386.

21. Rougeot C, Tiberghein C, Minary P, Dray F (1991) Basal and PAF-, interleukin $1-$, ether stress-induced hypothalamic pituitary adrenal secretion of conscious rat: modulation by PAF antagonists. J Lipid Mediat 4: 45-59.

22. Engvall E (1980) Enzyme immunoassay ELISA and EMIT. Methods Enzymo 70: 419-439

23. Zheng R, Shen R, Goodman OB Jr, Nanus DM (2006) Multiple androgen response elements cooperate in androgen regulated activity of the type 1 neutral endopeptidase promoter. Mol Cell Endocrinol 259: 10-21.

24. Iwase A, Ando H, Nagasaka T, Goto M, Harata T, et al. (2007) Distribution of endothelin-converting enzyme-1 and neutral endopeptidase in human endometrium. J Histochem Cytochem 55: 1229-1235.

25. Chia SE, Ong CN, Chua LH, Ho LM, Tay SK (2000) Comparison of zinc concentrations in blood and seminal plasma and the various sperm parameters between fertile and infertile men. J Androl 21: 53-57.

26. Tong Y, Tar M, Melman A, Davies K (2008) The opiorphin gene (ProL1) and its homologues function in erectile physiology. BJU Int 102: 736-740.

27. Gnessi L, Fabbri A, Spera G (1997) Gonadal peptides as mediators of development and functional control of the testis: an integrated system with hormones and local environment. Endocr Rev 18: 541-609.

28. Fujiwara H, Imai K, Inoue T, Maeda M, Fujii S (1999) Membrane-bound cell surface peptidases in reproductive organs. Endocr J 46: 11-25.

29. Agirregoitia E, Valdivia A, Carracedo A, Casis L, Gil J, et al. (2006) Expression and localization of delta-, kappa-, and mu-opioid receptors in human spermatozoa and implications for sperm motility. J Clin Endocrinol Metab 91: 4969-4975.

30. Subirán N, Agirregoitia E, Valdivia A, Ochoa C, Casis L, et al. (2008) Expression of enkephalin-degrading enzymes in human semen and implications for sperm motility. Fertil Steril 89: 1571-1577.

31. Subirán N, Candenas L, Pinto FM, Cejudo-Roman A, Agirregoitia E, et al. (2012) Autocrine regulation of human sperm motility by the met-enkephalin opioid peptide. Fertil Steril 98: 617-625.

32. Kotynia A KE, Czapor H, Brasun J (2010) The synthesis of opiorphin and studies on its binding ability toward Cu(II). Tetrahedron Letters 51: 2486-2488.

33. Meisel H (1997) Biochemical properties of regulatory peptides derived from milk proteins. Biopolymers 43: 119-128.

Citation: Dufour E, Villard-Saussine S, Mellon V, Leandri R, Jouannet P, et al. (2013) Opiorphin Secretion Pattern in Healthy Volunteers: Gender Difference and Organ Specificity. Biochem Anal Biochem 2: 136. doi:10.4172/2161 1009.1000136
34. Clare DA, Swaisgood HE (2000) Bioactive milk peptides: a prospectus. J Dairy Sci 83: 1187-1195.

35. Janecka A, Fichna J, Mirowski M, Janecki T (2002) Structure-activity relationship conformation and pharmacology studies of morphiceptin analogues--selective mu-opioid receptor ligands. Mini Rev Med Chem 2: 565-572.

36. Kost NV, Sokolov OY, Kurasova OB, Dmitriev AD, Tarakanova JN, et al. (2009) Beta-casomorphins-7 in infants on different type of feeding and different levels of psychomotor development. Peptides 30: 1854-1860.

37. Atherton AJ, Anbazhagan R, Monaghan P, Bartek J, Gusterson BA (1994) Immunolocalisation of cell surface peptidases in the developing human breast. Differentiation 56: 101-106

38. Imai K, Kanzaki H, Fujiwara H, Maeda M, Ueda M, et al. (1994) Expression and localization of aminopeptidase $\mathrm{N}$, neutral endopeptidase, and dipeptidy peptidase IV in the human placenta and fetal membranes. Am J Obstet Gynecol 170: 1163-1168.

39. Imai K, Kanzaki H, Mori T (1996) Cell surface peptidases in human endometrium. Mol Hum Reprod 2: 425-431.

40. Cripps MM, Bennett DJ (1992) Proenkephalin A derivatives in lacrimal gland occurrence and regulation of lacrimal function. Exp Eye Res 54: 829-834.

41. Meneray MA, Fields TY, Bennett DJ (1998) Gi2 and Gi3 couple met-enkephalin to inhibition of lacrimal secretion. Invest Ophthalmol Vis Sci 39: 1339-1345.

42. Zagon IS, Campbell AM, Sassani JW, McLaughlin PJ (2012) Spontaneous episodic decreased tear secretion in rats is related to opioidergic signaling pathways. Invest Ophthalmol Vis Sci 53: 3234-3240.

43. Brkljačić L, Sabalić M, Salarić I, Jerić I, Alajbeg I, et al. (2011) Development and validation of a liquid chromatography-tandem mass spectrometry method for the quantification of opiorphin in human saliva. J Chromatogr B Analyt Technol Biomed Life Sci 879: 3920-3926.

44. Holzer P, Holzer-Petsche U (1997) Tachykinins in the gut. Part II. Roles in neural excitation, secretion and inflammation. Pharmacol Ther 73: 219-263.

45. Lundy FT, Linden GJ (2004) NEUROPEPTIDES AND NEUROGENIC MECHANISMS IN ORAL AND PERIODONTAL INFLAMMATION. Crit Rev Ora Biol Med 15: 82-98.

46. Sato $Y$, Itoh H, Suzuki Y, Tatsuta R, Takeyama M (2013) Effect of pilocarpine on substance $\mathrm{P}$ and calcitonin gene-related peptide releases correlate with salivary secretion in human saliva and plasma. J Clin Pharm Ther 38: 19-23.

47. Braud A, Vandenbeuch A, Zerari-Mailly F, Boucher Y (2012) Dental afferents project onto gustatory neurons in the nucleus of the solitary tract. J Dent Res 91: $215-220$

48. Rougeot C (2009) Method for identifying BPLP and opiorphin agonists or antagonists.: In PCT/EP2009/050567 (WO/2009/090265, Ed.). 